\title{
2013-2018 Yılları Arasında Türkiye'de Meydana Gelen Yürüyen Merdiven Kazalarının İstatistiksel Olarak İncelenmesi
}

\author{
Statistical Analysis of Escalator Related Accidents in Turkey Between 2013-2018
}

\author{
Ali Kaan ÇOKTU (D) , Hasan Basri ULAŞ
}

\begin{abstract}
ÖZET
Bu makale kapsamında, geçmiş dönemde yaşanmış yürüyen merdiven kazaları için kaza karakteristikleri ve risk faktörlerini dikkate alarak istatistiksel bir değerlendirme yapılması amaçlanmaktadır. Bu kapsamda 2013-2018 yılları arasında Türkiye'de yaşanmış 485 yürüyen merdiven kazası incelenmiștir. Bu çalışma kapsamında yaşanmış kazalar ile ilgili veriler İş Sağlığı ve Güvenliği Bilgi Yönetim Sistemleri üzerinden toplanmıș olup, kazanın yeri, zamanı, yaş, cinsiyet, iş tecrübesi gibi kazazedeye yönelik tanımlayıcı bilgiler ile yaralanma durumu, iş göremezlik süreleri gibi kaza sonucuna ait bilgiler elde edilmiştir. İstatistiksel analizlerden sonra elde edilen sonuçlar ışığında, kazaların yaralanma türlerine göre toplamda 10 farklı kategoride yer aldığı tespit edilmiștir. Bu kategoriler içinde yüzeysel yaralanma ile sonuçlanan kazalar (\%40,6) ilk sırada olup 308 iş günü kaybına sebep olmuştur. Burkulma, incinme başlığında yer alan kazalar tüm kazaların \%23,2'si, açık yara ile sonuçlanan kazalar ise tüm kazaların \%13'ünü olușturmaktadır. Tüm kazaların \%77,1'i 3 ve daha az iş günü kayıplı kazalardan oluşmaktadır. Mevcut kaza verilerine dayalı olarak hazırlanan bu çalışma çıktıları itibariyle yürüyen merdiven kazalarını önleme ve yürüyen merdivenlerle ilgili önleyici tedbirlerin alınmasında önceliklendirilecek çalışmalara karar verme noktasında katkı sunmaktadır.

Anahtar Kelimeler: Yürüyen merdiven, iş kazası, iş güvenliği, kaza istatistiği
\end{abstract}

\section{ABSTRACT}

Within the scope of this article, it is aimed to make a statistical evaluation for escalator accidents experienced in the previous periods by taking into account the accident characteristics and risk factors. In this context, 485 escalators accident that occurred in Turkey between 2013 and 2018 have been investigated. In this study, data related to accidents have been collected through Occupational Health and Safety Information Management Systems, and descriptive information about casualty such as location, time, age, gender, work experience and information such as injury status and incapacity periods were obtained. The results obtained after statistical analysis show that accidents are classified into 10 different categories according to injury types. Among these categories, accidents resulting in superficial injuries were in the first place at $40.6 \%$, causing a loss of 308 working days. Accidents in the sprain and strain account for $23.2 \%$ of all accidents and accidents resulting in open wounds account for $13 \%$ of all accidents. $77.1 \%$ of all accidents are accidents with loss of 3 days and less working days. As a result of this study, that is prepared based on the existing accident data, it contributes to the prevention of escalator accidents and the decisions to be prioritized in taking preventive measures related to escalators.

Keywords: Escalator, accident, occupational safety, accident statistics

Ali Kaan ÇOKTU I kaancoktu@gmail.com

Aile, Çalışma ve Sosyal Hizmetler Bakanlığı, AÇSH Uzmanı, Ankara, Türkiye

The Ministry of Family, Labour and Social Services, FLSS Expert, Ankara, Turkey

Hasan Basri ULAŞ | bulas@gazi.edu.tr

Gazi Üniversitesi, Teknoloji Fakültesi, Ankara, Türkiye

Gazi University, Faculty of Technology, Ankara, Turkey 


\section{GİRIŞ}

Özellikle 2000'li yılların başından itibaren, yürüyen merdivenler hızlı ve güvenilir şekilde insan taşınmasında önemli bir rol oynamıştır. Yürüyen merdivenler, alışveriş merkezleri, havalimanları, iş merkezleri, metro istasyonları, alt ve üst geçitler gibi yoğun insan trafiği olan ve kısa mesafelerde asansörlerin trafiği karşılayamadığı yerlerde kesintisiz insan trafiği sağlama rolü üstlenerek yaşam kalitesini artıran önemli bir iş ekipmanıdır. Asansörler ve yürüyen merdivenler, kurulum, tamir ve bakım süreçlerinde çalışanlar açısından, kullanım aşamasında ise kullanıcılar açısından ölüm veya ciddi yaralanmalı kaza geçirme potansiyeli bulunduran ekipmanlardır[1]. Yürüyen merdivende yaşanan kazalar travmatik ölümlü vakalara sebebiyet verebilir. Yürüyen merdiven kaza sayısı, asansör kaza sayısından 20 kat daha fazladır[2]. İş ekipmanlarının kullanımında sağlık ve güvenlik şartları yönetmeliğinde de vurgulandığı üzere, güvenli kullanım, periyodik kontrol ve bakım faaliyetleri ekipman güvenliğinin sağlanmasında yüksek önem arz etmektedir. Yürüyen merdivenler, toplu halde yaralanma veyahut ölümle sonuçlanan kazaların yaşanabileceği önemli bir kaldırma iletme grubu ekipmanıdır. Ekipman güvenliğinin sağlanması, insan güvenliğinin temin edilmesinde en önemli bileşenlerden biridir. Günlük hayatımızda yoğun olarak kullanılmaya başlanan bu ekipmanlarda, özellikle kurulum, periyodik kontrol, bakım ve günlük kullanım esnasında oluşan kazalar ile ilgili çok çarpıcı vakalar yaşanmaktadır. Günümüzde Avrupa Birliği $(A B)$ ve $A B$ Serbest Ticaret Bölgesi'nde 75.000 'den fazla yürüyen merdiven ve yürüyen bant mevcuttur. Bunların yarısından çoğu 20 yıl ve öncesinde kurulmuştur. Teknolojik gelişmeler ve sosyal beklentiler bugünkü güvenlik standartlarına öncülük etmiştir. Yürüyen bant ve merdivenlerin ömrü diğer araçlara nazaran daha uzun ömürlü olduğundan tasarım, performans ve güvenlik olarak modern teknolojinin gerisinde kalmıştır. Eğer mevcut yürüyen bant ve merdivenlerin güvenliği modern teknolojiye göre iyileştirilmezse, gelecekte birçok kazaya yol açma ihtimali yüksektir [3].

Yürüyen merdiven ve bantlarda oluşabilecek risklerin önlenmesi adına imalatçlar için “TS EN 115-1:2017 Yürüyen merdiven ve yürüyen bantlar için güvenlik - Bölüm 1: Yapım ve montaj” standardı uygulanırken, bugünün modern güvenlik uygulamaları sayesinde yeni kurulan yürüyen merdiven ve yürüyen bantlarda eşdeğer seviyede güvenliğe erişmek amacıyla mevcut olan yürüyen merdiven ve yürüyen bantlardaki güvenliği geliştirmeyi amaçlayan kurallar "TS EN 115-2. Yürüyen merdiven ve yürüyen bantlar için güvenlik - Bölüm 2: Mevcut yürüyen merdiven ve yürüyen bantların güvenliğinin iyileştirilmesi için kurallar" standardında düzenlenir. Söz konusu standartlar Türkiye'de iş ekipmanlarının kullanımı ile ilgili alanı düzenleyen 28628 sayılı Resmi Gazete'de yayımlanan İş ekipmanlarının kullanımında sağlık ve güvenlik şartları yönetmeliğiyle uyumlu ve destekleyici standartlardır.

Aşağıda yürüyen merdiven sistemlerinin ana bileşenleri ve fonksiyonları belirtilmiştir.

Tablo 1. Yürüyen merdiven yapısı ve işlevi [4]

Ekipman Bileşeni

Ana Fonksiyon

Merdiven Sistemi

Sapmayı önlemek için ana teker ve yardımcı tekerden geçen yükü destekler.

Tahrik sistemi

Yürüyen merdivenin güç kaynağıdır.

Korkuluk

Yürüyen merdiven dengesini korur.

Ana fonksiyonu, merdivene binen insanların kıyafet vb. sıkışmasına imkân vermeden yaralanmalarını engellemek.

Elektrik sistemi
Yürüyen merdivenin kontrolünü sağlamak. 
Yürüyen merdivenler, çok yaygın olarak kullanılmaları sebebiyle kazaya meyilli yerler olarak dikkat çekmeleri beklenen bir durumdur. Yılllk olarak rapor edilen kayıtlara göre, Amerika'da her yıl 10.000 yürüyen merdiven kaynaklı tedavi gerektiren kaza yaşanmaktadır [5]. Çin Halk Cumhuriyeti Kalite Kontrol, Muayene ve Karantina Genel Müdürlüğü kayıtlarına göre, yürüyen merdiven kazaları son yillarda sürekli olarak en çok kaza yaşanan ekipmanların başında gelmektedir [6].

Şekil 1: 2009-2014 yıllarında Çin'de yaşanan yürüyen merdiven kazaları

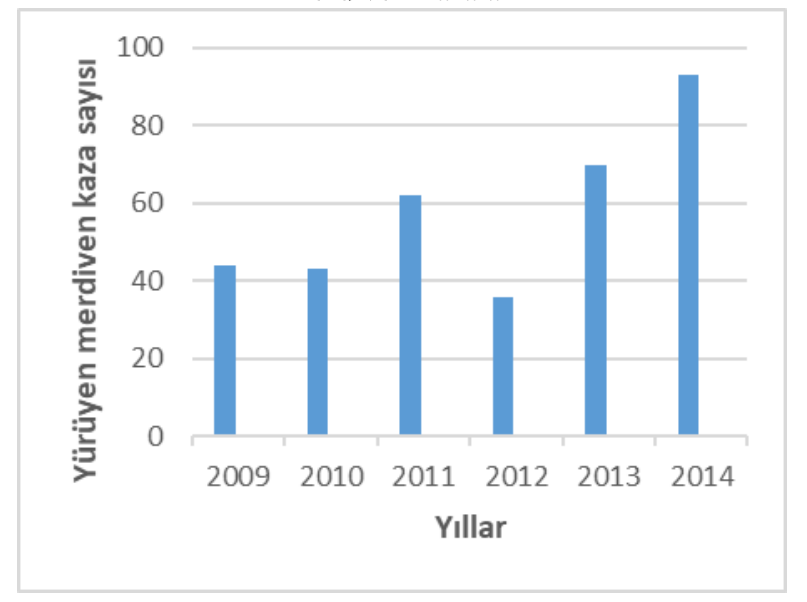

Yürüyen merdiven kaza kayıtlarının analizine yönelik $A B D$ ve bazı Asya bölgesi ülkelerinde yapılan çalışmalar bulunmasına rağmen Türkiye'de, yürüyen merdiven kaza kayıtları ve analizi özelinde bir çalışma bulunmamaktadır. Yapılan çalışmalar incelendiğinde özellikle çocuk ve yaşlı grubu insanlarda yürüyen merdiven kazalarının sıklıkla yaşandığı dikkat çekmektedir. Yürüyen merdiven kazaları farklı yaş gruplarında sıklıkla yaşanmasına rağmen iş kazası tanımı kapsamında değerlendirilmeyen kazalara ait verilere erişilememesi sebebiyle, sadece çalışanların yaşadığı ve iş kazası olarak kayıt altına alınan yürüyen merdiven kazaları bu çalışma kapsamında ele alınmıştır. Bu çalışma, çocuklar ve yaşılıar ile ilgili yapılan önceki çalışmalardan farklı olarak, çalışanların yürüyen merdivende geçirdiği iş kazaları- nın epidemiyolojik özelliklerini ve türlerini belirlemeyi amaçlamaktadır.

Bu çalışma kapsamında, 25.04.2013 tarih ve 28628 sayılı Resmi Gazetede yayımlanan ve mevcut durumda yürürlükte olan "İş ekipmanlarının kullanımında sağlık ve güvenlik şartları yönetmeliğinde” yer alan yürüyen merdivenler için İşs sağlığı güvenliği bilgi yönetim sisteminden (İBYS) elde edilen iş kazası kayıtlarına yansıyan sonuçların istatistiksel analizi ve değerlendirilmesi amaçlanmaktadır.

1990'lı yllardan itibaren yürüyen merdivenler ile ilgili kaza kayıtları ve kaza trendlerini ele alan istatistiksel çalışmalar mevcuttur. Bununla birlikte özellikle insan, yürüyen merdiven etkileşimi, yürüyen merdivenlerin kullanım ora$\mathrm{n} ı$, yürüyen merdiven bileşenlerinin fiziksel özelliklerinin analizi ve tasarıma yönelik çalışmalar literatürde yer almaktadır. İş güvenliği ekseninde yapılan çalışmalara bakacak olur isek, 1997 yılında Platt ve arkadaşları tarafından yapılan çalışmada 18 yaşından küçük bireyler özelinde yaşanan 1990-1995 yılları arasındaki 26 yürüyen merdiven kazası incelenmişsir[7]. Risk faktörleri, yaralanma türleri ve uzun dönemli etkiler gibi durumların araştırıldığı bu çalışmada, yaşanan kazaların \%65'inin bel altı vücut bölgeleri, \% 31'inin ise bel üstü vücut bölgelerini etkileyen kazalar olduğu sonucuna ulaşılmıştır. Mcgeehan ve arkadaşları 2006 yılında yaptıkları çalışmada 1990-2002 yılları arasında Amerika'da çocukların yaşadığı yürüyen merdiven kaynaklı kazaları incelemişlerdir. Her yıl yaklaşık 2.000 çocuğun yürüyen merdiven kazası sonucu sağlık kuruluşlarından hizmet aldığı sonucuna ulaşılmıştır[8]. Chi ve arkadaşları da yine 2006 yılında yaptıkları bir çalışmada 2000 yllında yaşanmıs 194 yürüyen merdiven kazası için kaza nedenlerine yönelik istatistiksel bir çalışma yürütmüşlerdir. Çalışma sonucuna göre, yaralanmaya neden olan durumlar yürüyen merdivende başka bir şeyle uğraşma, düşme, el bandını tutmama veya bir başkasının çarpması sonucu yaralanma 
gibi sebeplerden oluştuğu bulgusu elde edilmiştir[9]. Nicolson, 2008 yılında yayınladığ diven kaynaklı kazaların oluşmasında en önemli etkenin insan faktörü olduğunu belirtmiştir[10]. McCann ve Zaleski 2013 yılında yaptıkları çalışmada, 1997-2010 Haziran arası gerçekleşmiş ölümle sonuçlanan yürüyen merdiven kaza kayıtlarını incelemişlerdir. Yapılan analizler sonucunda yürüyen merdiven kazasında oluşan ölümlerin \% 75 'inden fazlasının düşme sebebiyle olduğu sonucu ortaya çıkmıştır[11]. Lee ve arkadaşları 2010 yılında yayınladıkları çalışmada 2004-2008 yılları arasında meydana gelmiş yürüyen merdiven kaynaklı kazaların sayıları ve oluş şekillerini ele almışlardır. Araştırma sonuçlarına göre yer altı metro istasyonları en fazla kaza yaşanan yer olurken, 65 yaş üstü yaş grubu ise en yüksek riske sahip grup olarak tespit edilmiştir [12]. Schminke ve arkadaşlarının 2012 yılında yayınladıkları çalışmada ise 16 yaş üstü 173 kişide yaşanmış 285 yürüyen merdiven yaralanması incelenmiş ve ciddi travmalar ile sonuçlanabilecek seviyede kazaların yaşanabildiğine vurgu yapılmıştır. Yaş ve alkol tüketiminin yürüyen merdiven kazalarını artırıcı etkenler olduğu belirtilmiştir [5]. Howland ve arkadaşlarının 2012 yılında yürüttükleri çalışmada ABD-Metropolitan Havalimanında gerçekleşen 2009-2010 yıllarına ait yaşlı insanların geçirmiş oldukları düşme kazalarının \%44’ünün yürüyen merdiven kazası olduğu tespit edilmiştir[13]. 2014 yllında, Ertürk Karatekin tarafından yayınlanan çalışmada, mevcut yürüyen merdiven ve bantlardaki kontrol noktaları ve bu noktaların güvenlik açısından önemi incelenmiştir. Avrupa ülkelerine ait kaza istatistiklerine vurgu yapılan çalışmada kazaların \% 44 'ünün 10 yaş ve altı çocuklarda olduğu belirtilmiştir. Yapılan çalışmada, imalat standartlarına uygun üretilen ürün kullanarak ve teknolojik gelişmeleri üretime adapte ederek ölümle sonuçlanan kazaların \%25 oranında azaltılabileceği vurgulanmıştır[3].
Yürüyen merdiven özelinde yapılan çalışmaların ağırlıklı odak noktasını çocuk ve yaşlı grubu insanlar oluşturmuştur. Bu tür çalışmalardan biri olan 2016 yllında Chen ve Xian tarafından yürütülen ve Çin'in Guandgdong şehrinde anaokuluna giden çocukların yaşadığı 609 yürüyen merdiven kazası incelenmiştir. Bu çalışma kapsamında kazaların oluşmasındaki en önemli sebebin kıyafetler olduğu tespit edilmiştir. Özellikle terlik, elbise ve sırt çantalarının ipleri bu kazaların oluşmasında en önemli nedenler olarak görülmüştür[14].

2018 yılında Basir ve arkadaşlarının yayınlamış olduğu çalışmada, yürüyen merdiven arızaları ve yürüyen merdiven tasarımlarının, yürüyen merdiven kaynaklı kazaların oluşmasında orta düzeyde pozitif ilişkili olduğu tespit edilmiştir $(r=0,53$ ve $r=0,50$ burada $r$ Pearson korelasyon katsayısdir.) [15].

2019 yılında Xing ve arkadaşlarının yayınladığı çalışmada, 2013-2015 yılları arasında Çin'deki metro istasyonlarında bulunan yürüyen merdivenlerde yaşanmış $950 \mathrm{ka}-$ za, kaza karakteristikleri ve risk faktörlerini belirlemek adına istatistiksel olarak analiz edilmiştir. Çalışma kapsamında kazaların \%30’luk kısmının denge kaybından oluştuğu sonucu elde edilmiştir [6].

En yakın tarihli çalışma 11 Ocak 2020'de Xing Y. ve arkadaşları tarafından yayınlanmıştır. Bu çalışmada, metro istasyonlarındaki yürüyen merdiven güvenliğini etkileyen risk faktörlerini tanımlamak için Bayes ağı kullanılarak yürüyen merdivenle ilgili yaralanmaların olasılık ve şiddet analizi gerçekleştirilmiştir. 950 yürüyen merdiven kaynaklı kazanın analiz edildiği çalışmada kazazedelerin \%64’ü kadın olup, tüm kazaların \%65’i 9:30-17:29 saatleri arasında yaşanırken, \%90 oranında düşme ile sonuçlanan kazanın olduğu tespit edilmiştir [16]. 


\section{YÖNTEM}

\section{A. Veri Toplama}

Bu çalışma kapsamında, iş kazası olarak değerlendirilen ve 2013-2018 yıllarında yaşanan yürüyen merdiven kaza kayıtları İBYS üzerinden çekilmiştir. İBYS, İş Sağlığı ve Güvenliği Genel Müdürlüğü tarafından kullanılan, önleyici stratejilerin geliştirilmesini amaçlayan, farklı alanlara yönelik verilerin bulunduğu bir sistemdir[17]. Bu kapsamda işyerleri ve çeşitli kurumlardan veriler çekilmektedir. İş kazası kayıtlarının toplandığı Sosyal Güvenlik Kurumu kayıtları da bu program kapsamında çekilmektedir. Türkiye, $A B$ müktesebatına uyum çerçevesinde iş sağlığı ve güvenliği alanındaki mevzuatını uyumlaştırırken, iş kazalarının kayıt alıına alınması ile ilgili olarak da Avrupa İş Kazası İstatistikleri (ESAW) metodolojisini uygulamaktadır [18]. ESAW metodolojisi, olayı normal seyrinden saptıran durum, yaralanmaya sebep olan hareket, yaranın türü gibi

Tablo 2: Kaza zamanı ile ilgili parametreler ve alt kategorileri

\begin{tabular}{|c|c|c|}
\hline Değişken & \multicolumn{2}{|c|}{ Alt Kategori } \\
\hline \multirow{3}{*}{ Kaza Yılı } & 2013 & 2014 \\
\hline & 2015 & 2016 \\
\hline & 2017 & 2018 \\
\hline \multirow{6}{*}{ Kaza Ayı } & Ocak & Şubat \\
\hline & Mart & Nisan \\
\hline & Mayıs & Haziran \\
\hline & Temmuz & Ağustos \\
\hline & Eylül & Ekim \\
\hline & Kasım & Aralık \\
\hline \multirow{4}{*}{ Kaza Günü } & Pazartesi & Salı \\
\hline & Çarşamba & Perşembe \\
\hline & Cuma & Cumartesi \\
\hline & \multicolumn{2}{|c|}{ Pazar } \\
\hline \multirow{3}{*}{ Kaza Saati } & 00:01-07:59 & $08: 00-11: 59$ \\
\hline & $12: 00-15: 59$ & $16: 00-19: 59$ \\
\hline & \multicolumn{2}{|c|}{ 20:00-00:00 } \\
\hline
\end{tabular}

kazayı analiz ederken kategorilendirme yapmayı kolaylaştıran ve Avrupa Birliği ülkeleri içinde karşılaştırılabilir veri sunmayı amaçlayan bir yaklaşım gütmektedir. Ancak kaza kayıtlarının oluşturulması aşamasında istenen bilgiler teknik literatüre uygun olarak girilmediği için öncelikli olarak anahtar kelime olan "yürüyen merdiven" ile tarama yapılmış ve çıkan tüm sonuçlar için kaza açıklamaları incelenmek suretiyle kazanın yürüyen merdiven ile ilgili bir kaza olup olmadığı tespit edilmiştir. Bu çalışma kapsamında 2013-2018 yılları arasında yaşanan 485 yürüyen merdiven kazasına ait kaza kayıtları ayrıntılı olarak incelenmiş, kazaya sebebiyet veren olaylar kök nedenlerine bağlı incelenmiş, oluşan kaza sonucu kişinin yaralanma şekli, vücudun etkilenen kısmı, kazanın vücuttaki etkisi gibi parametreler ışığında değerlendirme yapılmıştır.

\section{B. Verilerin Değerlendirilmesi}

Tanımlayıcı istatistiksel analizlerin yapılabilmesi için ölümlü iş kazalarına ilişkin kaza bildirim formlarındaki bilgiler ESAW metodolojisi dikkate alınarak kategorilendirme açısından yeniden ele alınmıştır. Değişken karakteristikleri ile ilgili olarak üç farklı kategori altında gruplanan 15 farklı değişken çalışma kapsamında incelenmiştir. Bu kategoriler; kaza zamanı, kazazede ve kazaya ait karakteristikleridir.

Tablo 3: Kazazede ile ilgili parametreler ve alt kategorileri

\begin{tabular}{ccc}
\hline Değişken & \multicolumn{2}{c}{ Alt Kategori } \\
\hline \multirow{2}{*}{ Yaş } & $15-24$ & $25-32$ \\
& $33-40$ & $41-50$ \\
\hline Cinsiyet & $51+$ & \\
\hline \multirow{2}{*}{ Medeni Hal } & Kadın & Erkek \\
& Bekar & Evli \\
\hline \multirow{2}{*}{ Eğitim Durumu } & Boşanmış & Bilinmeyen \\
\hline isG Eğitimi & ilkokul & Ortaokul \\
\hline
\end{tabular}


Tablo 4: Kaza ile ilgili parametreler

\begin{tabular}{|c|c|c|}
\hline Değişken & & \\
\hline İş günü kaybı (Yaralanma Şiddeti) & $<=3$ gün & $>=4$ gün \\
\hline \multirow[t]{2}{*}{ Yaralanma Türü(Sonuç) } & $\begin{array}{c}\text { Kırık } \\
\text { Burkulma, incinme } \\
\text { Çatlak } \\
\text { Elektrik şoku } \\
\text { Yüzeysel yaralanma }\end{array}$ & $\begin{array}{c}\text { Açık yara } \\
\text { Çatlak } \\
\text { Çıkık } \\
\text { Diğer tür yaralanma } \\
\text { Uzuv kaybı }\end{array}$ \\
\hline & \multicolumn{2}{|c|}{ Yanma, haşlanma, soğuk yaraları } \\
\hline ISG Eğitimi & Var & Yok \\
\hline \multirow{7}{*}{$\begin{array}{l}\text { Kazaya Sebebiyet } \\
\text { Veren Olay }\end{array}$} & Bayılma & $\begin{array}{l}\text { Elektrik sorunları, patlama, } \\
\text { yangın nedeniyle sapma }\end{array}$ \\
\hline & $\begin{array}{l}\text { Fiziki baskı olmadan beden } \\
\text { hareketi }\end{array}$ & $\begin{array}{l}\text { İş birliği olmaksızın yapılan hareket, } \\
\text { gereksiz veya zamansız eylemler }\end{array}$ \\
\hline & $\begin{array}{l}\text { Fiziki baskıyla veya fiziki baskı altında } \\
\text { beden hareketi }\end{array}$ & Taşınan cismin denetim kaybı \\
\hline & Bayılma & $\begin{array}{l}\text { Elektrik sorunları, patlama, } \\
\text { yangın nedeniyle sapma }\end{array}$ \\
\hline & $\begin{array}{l}\text { Fiziki baskı olmadan beden } \\
\text { hareketi }\end{array}$ & $\begin{array}{l}\text { İş birliği olmaksızın yapılan hareket, } \\
\text { gereksiz veya zamansız eylemler }\end{array}$ \\
\hline & Kayma veya tökezleme & $\begin{array}{c}\text { Maddi aracın kırılma, patlama, ayrılma, } \\
\text { kayma, düşme, çökmesi }\end{array}$ \\
\hline & Makine denetim kaybı & Şok korku vahşet saldırganlık tehdit \\
\hline \multirow{4}{*}{$\begin{array}{l}\text { Yaralanmaya Sebep } \\
\text { Olan Olay }\end{array}$} & Elektrik akımı ısı tehlikeli, maddelerle temas & Kas iskelet sistemi üzerinde fiziksel baskı \\
\hline & Fiziksel veya zihinsel baskı & Hareket halindeki bir nesnenin çarpması \\
\hline & Isırılma, tekme vb. & Kısılma ezilme \\
\hline & $\begin{array}{l}\text { Sabit bir nesneye yatay } \\
\text { veya düşey darbe }\end{array}$ & $\begin{array}{l}\text { Sivri uçlu sert veya kaba bir } \\
\text { materyal ile temas }\end{array}$ \\
\hline \multirow{7}{*}{ Vücudun Etkilenen Kısmı } & Ayak & Bacak \\
\hline & Bel & Boyun \\
\hline & Kol & Dirsek \\
\hline & El & Gövde \\
\hline & Göz & Omuz \\
\hline & Sirt & Kafa \\
\hline & $\begin{array}{l}\text { Bedenin etkilenmiş birden } \\
\text { fazla bölümü }\end{array}$ & Belirtilmemiş \\
\hline
\end{tabular}

\section{Tanımlayıcı İstatistikler}

$\mathrm{Bu}$ çalışmada veri setinin detaylı incelenmesi için tanımlayıcı istatistik teknikleri kullanılmıştır. Tanımlayıcı istatistikler örneklem ve yapılan gözlemlere ilişkin özet bilgiler vermesi açısından önemlidir. Tanımlayıcı analizin iki tipi vardır. Bunlardan biri olan tek değişkenli analiz, çeşitli veri setleri üzerinde istatistiksel analiz yapan araştırmacıların genellikle kullandıkları, veri seti üzerinde uyguladıkları ilk analizdir. İş güvenliği alanında yapılan çalışmalar için de aynısını söylemek mümkündür[19]. Bir diğer tanımlayıcı istatistik türü ise çapraz tablolamadır. Bu çalışmada, tek değişkenli sıklık analizi verisetinin daha net anla- şılması ve yorumlanması amacıyla kullanılmıştır. Ayrıca değişken kategorilerinin ayrılmasında tek değişkenli sıklık analizinden faydalanılmıştır. $\mathrm{Bu}$ analizlerde elde edilen sonuçlar sıklık tabloları ile paylaşılmıştır.

$\mathrm{Bu}$ çalışmanın amaçlarından biri, verisetinde kaza şiddeti olarak tanımlanan, sonuç ile bağlantısı olan ve kaza şiddetine etki eden faktörlerin neler olduğunun belirlenmesidir. Bu nedenle, bu çalışmada tek değişkenli sıklık analizi ile birlikte mevcut veriseti kullanılarak çapraz tablolama yardımıyla ikili analizler uygulanmıştır. Çalışma kapsamında incelenen değişkenler bağımlı ve bağımsız değişkenler olarak ayrılmıştır. Yaşanan 485 kaza arasında ölümlü kaza 
olmadığı için yaralanmalı kazalar arasında iş günü kaybına bağlı bir değerlendirme yapılmış ve iş günü kaybı (yaralanma şiddeti) değişkeni "Bağımlı değişken” olarak seçilmiştir. Bunun dışında kalan değişkenler bağımsız değişken olarak analizlerde kullanılmıştır. Hem tek değişkenli sıklık hem de çapraz tablolama analizlerinde SPSS 20 yazılımı kullanılmıştır.

\section{BULGULAR}

Çalışma kapsamında elde edilen tek değişkenli analiz sonuçları ve çapraz tablolama sonuçları bu başlık altında sunulmuştur. Tek değişkenli analiz sonuçları kazazede, zaman ve kaza ile ilgili Tablo 5-6-7'de belirtilen parametrelerle 3 grupta incelenmiştir. 2013-2018 yılları arasında yaşanan 485 yürüyen merdiven kazası incelendiğinde en çok kaza \%30,31 oranında 2017 yılında yaşanmıştır. Aylara göre yürüyen merdiven kaza dağılımı incelendiğinde Şubat \%10,5 ile en sık şekilde kaza yaşanan ay olarak tespit edilmiştir. Kış ayları olarak değerlendirilen Kasım, Aralık, Ocak ve Şubat aylarında görülen kaza oranı \%38,4 iken, yaz ayları olan Haziran, Temmuz, Ağustos ve Eylül aylarında geçirilen kazaların oranı \%32,2 olarak tespit edilmiştir. Özellikle AVM, metro istasyonu gibi toplu insan etkileşimi olan yerlerde yürüyen merdiven kazaları sık görülmesine rağmen \%9,1 ile cumartesi günü yaşanan kazaların en az oranda tespit edilmesi dikkat çekmektedir. Bununla birlikte, yine insan etkileşiminin yoğun olduğu bu tür işyerlerinde insan yoğunluğunun fazla olduğu 10:00-18:00 saatleri arasında yer alan gündüz kuşağında tüm yürüyen merdiven kazalarının \%77,1'i yaşanmıştır. Tüm yürüyen merdiven kazası geçiren kişilerin iş tecrübelerinin ortalama 10,18 ay olduğu tespit edilmiştir. Kazazedelerin yaş ortalaması ise 30 olarak bulunmuştur. Tüm kazazedelerin 265 tanesi erkek, 220 tanesi kadındır. Kazazedelerin \%93'ü temel iş sağlı̆̆ ve güvenliği eğitimini almıştır. Kazazedelerin \%49,6'1 bekâr, \%42,6's1 evlidir. \%33,2 ile en çok 15-24 yaş grubunda yer alan genç çalışanlar kaza geçirmektedir. Bunları \%32 ile 25-32 yaş aralığındaki çalışanlar takip etmektedir. Öğrenim durumlarına göre ortaöğretim mezunu çalışanlar \%42,6 ile en çok kaza yaşayan gruptur.

Tablo 5. Kazazede karakteristiği ile ilgili parametrelere ait bulgular

\begin{tabular}{|c|c|c|}
\hline Kazazede Yaşı & Kaza Sayısı & Kaza Oranı \\
\hline $15-24$ & 162 & $\% 33,2$ \\
\hline $25-32$ & 156 & $\% 32,0$ \\
\hline $33-40$ & 94 & $\% 19,3$ \\
\hline $41-50$ & 58 & $\% 11,9$ \\
\hline $51+$ & 15 & $\% 3,1$ \\
\hline Kazazede Cinsiyeti & Kaza Sayısı & Kaza Oranı \\
\hline Erkek & 265 & $\% 54,7$ \\
\hline Kadın & 220 & $\% 45,3$ \\
\hline Medeni Durumu & Kaza Sayısı & Kaza Oranı \\
\hline Evli & 208 & $\% 42,6$ \\
\hline Bekar & 242 & $\% 49,6$ \\
\hline Boşanmış & 33 & $\% 6,8$ \\
\hline Bilinmiyor & 2 & $\% 0,4$ \\
\hline Eğitim Durumu & Kaza Sayısı & Kaza Oranı \\
\hline Okur-Yazar & 35 & $\% 7,2$ \\
\hline İlköğretim & 166 & $\% 34,1$ \\
\hline Ortaöğretim & 208 & $\% 42,6$ \\
\hline Yüksek Öğretim & 76 & $\% 15,5$ \\
\hline isG Eğitimi & Kaza Sayısı & Kaza Oranı \\
\hline Var & 451 & $\% 93$ \\
\hline Yok & 34 & $\% 7$ \\
\hline
\end{tabular}

Çalışma kapsamında bağımlı değişken olan yaralanma şiddeti değişkeni kazazede karakteristiği altında yer alan parametrelere göre değerlendirilmiştir. Yaş gruplarına göre yaralanma şiddetleri farklılık göstermektedir. 4 ve üstü iş günü kayıplı kaza geçiren ve ağır yaralanmalı kaza olarak belirtilen kazalar en çok \%34,2 ile 25-32 yaş aralığında yer alan çalışanlarda görülürken, 3 ve altında iş günü kaybıyla sonuçlanan ve görece olarak hafif yaralanmalı kaza olarak belirtilen kazalar ise en çok \%35 ile 15-24 yaş aralığında görülmektedir. 3 ve altında iş günü kayıplı yaralanmalar erkeklerde \%50,3 kadınlarda \%49,7 ile cinsiyete göre bir- 
Tablo 6: Kaza zamanı ile ilgili parametrelere ait bulgular

\begin{tabular}{|c|c|c|}
\hline Kaza Yılı & Kaza Sayısı & Kaza Oranı \\
\hline 2013 & 33 & $\% 6,80$ \\
\hline 2014 & 58 & $\% 11,96$ \\
\hline 2015 & 63 & $\% 12,99$ \\
\hline 2016 & 91 & $\% 18,76$ \\
\hline 2017 & 147 & $\% 30,31$ \\
\hline 2018 & 93 & $\% 19,18$ \\
\hline Kaza Günü & Kaza Sayısı & Kaza Oranı \\
\hline Pazartesi & 78 & $\% 16,1$ \\
\hline Salı & 71 & $\% 14,6$ \\
\hline Çarşamba & 75 & $\% 15,5$ \\
\hline Perşembe & 84 & $\% 17,3$ \\
\hline Cuma & 66 & $\% 13,6$ \\
\hline Cumartesi & 44 & $\% 9,1$ \\
\hline Pazar & 67 & $\% 13,8$ \\
\hline Kaza Ayı & Kaza Sayısı & Kaza Oranı \\
\hline Ocak & 44 & $\% 9,1$ \\
\hline Şubat & 51 & $\% 10,5$ \\
\hline Mart & 30 & $\% 6,2$ \\
\hline Nisan & 35 & $\% 7,2$ \\
\hline Mayıs & 43 & $\% 8,9$ \\
\hline Haziran & 42 & $\% 8,7$ \\
\hline Temmuz & 37 & $\% 7,6$ \\
\hline Ağustos & 34 & $\% 7,0$ \\
\hline Eylül & 43 & $\% 8,9$ \\
\hline Ekim & 35 & $\% 7,2$ \\
\hline Kasım & 47 & $\% 9,7$ \\
\hline Aralık & 44 & $\% 9,1$ \\
\hline Kaza Saati & Kaza Sayısı & Kaza Oranı \\
\hline 00:01-07:59 & 56 & $\% 11,5$ \\
\hline 08:00-11:59 & 162 & $\% 34,4$ \\
\hline 12:00-15:59 & 122 & $\% 25,15$ \\
\hline $16: 00-19: 59$ & 95 & $\% 19,58$ \\
\hline
\end{tabular}

birine yakın oranlarda yaşanmış olup 4 ve üstü iş günü kayıplı kazaların \%69,4’ü erkeklerde görülmektedir. Ağır yaralanmalı kaza geçirenlerin \%36,2'si Lise mezunudur.

Tablo 7: Kaza karakteristiği ile ilgili bulgulara ait parametreler

\begin{tabular}{ccc}
\multicolumn{3}{c}{ ait parametreler } \\
\hline $\begin{array}{c}\text { İş Günü Kaybı } \\
\text { (Yaralanma Şiddeti) }\end{array}$ & Kaza Sayısı & Kaza Oranı \\
\hline YŞ1: 3 ve daha az gün \\
kaybı \\
YŞ2: 4 ve üstü gün kaybı & 374 & $\% 77,1$ \\
\hline
\end{tabular}

Yaşanan 485 yürüyen merdiven kazası sonucu toplamda 1.445 gün kaybı oluşmuştur. Yaklaşık olarak her yürüyen merdiven kazası sonucu 3 gün kayıp oluşmaktadır. Yaşanan 485 yürüyen merdiven kazası, oluşan iş günü kaybının süresine bağlı olarak iki grupta incelenmiştir. 3 ve daha az gün kaybı ile sonuçlanan kazalar tüm yürüyen merdiven kazalarının \%77,1'ini oluştururken, 4 ve daha fazla gün kaybı ile sonuçlanan kazaların oranı \%22,9 olarak tespit edilmiştir.2013-2018 yılları arasında ortalama günlük kazancın 80,81 TL olduğunu baz alırsak 1.445 gün kaybı için işverene oluşan görünür maliyet $117.000 \mathrm{TL}$ yapmaktadır[20]. Oransal olarak en fazla gün kaybına sebep olan yaralanma türü, taşınan nesnenin çarpması kategorisinde yer almaktadır. 3 ve alında iş günü kayıplı kazaların en önemli nedeni \%28,3 ile kayma veya tökezleme iken, 4 ve üstü iş günü kaybıyla sonuçlanan kazaların en önemli nedeni \%30,6 ile taşınan cismin kontrolünün kay-

Şekil 2: Yürüyen merdiven kazalarında yaralanma türleri

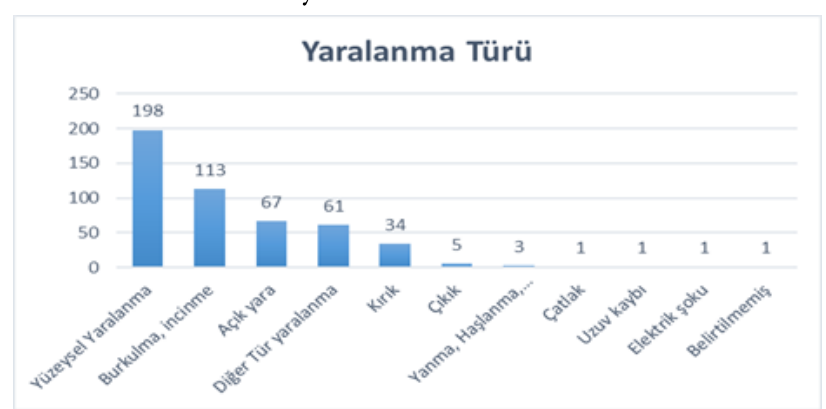


bedilmesidir. YŞ1 grubu kazaların \%48,3'ü bel üstü, \% 51,7'si bel altında bulunan bölgeleri etkileyen kazalardır. YŞ2 grubu kazaların ise \%47'si bel üstü, \%53’ü bel altı bölgesinde yaralanma oluşturmuştur.

Yürüyen merdivende meydana gelen kazalar sonucu, kaza şiddetine göre toplamda 10 farklı yaralanma türünün oluştuğu tespit edilmiştir. ESAW'da belirtilen yaralanma türlerine uygun şekilde kazalar kategorilendirilmiştir. Çalışma kapsamında yaralanma türleri incelenmiş olup 198 kaza ile tüm kazaların \%40,6'sının yüzeysel yaralanma kategorisinde olduğu tespit edilmiştir. ESAW Ek C yaranın türü sınıflandırması başlığında 011 başlığı alında yer alan yüzeysel yaralanmalar "çürük, ezik, kan toplanması, aşınma, sıyrık, su toplaması" gibi yaralanmaları ifade etmektedir. Yüzeysel yaralanmalar tüm kazaların \%40,6'sını oluşturmasına rağmen 308 iş günü kaybı ile tüm iş günü kayıplarının sadece \%21'ini oluşturmaktadır. Burkulma, incinme başlığında yer alan kazalar \%23,2 ile en çok görülen yürüyen merdiven kazası sonucu yaralanma türüdür. Bu yaralanma türüne bağlı olarak toplamda 343 iş günü kaybı oluşmuştur. Tüm kazaların sadece \%13'ünü oluşturan açık yara ile sonuçlanan kazalar da 304 gün iş günü kaybına sebebiyet vermiştir.

ESAW yaklaşımı kapsamında olay bütüncül olarak incelenip kazanın kök nedeninin tespit edilmesi amaçlanmaktadır. Bu kapsamda kazaya sebebiyet veren olay başl1-

Şekil 3: Yürüyen merdiven kazalarında kazaya sebebiyet veren olaylar

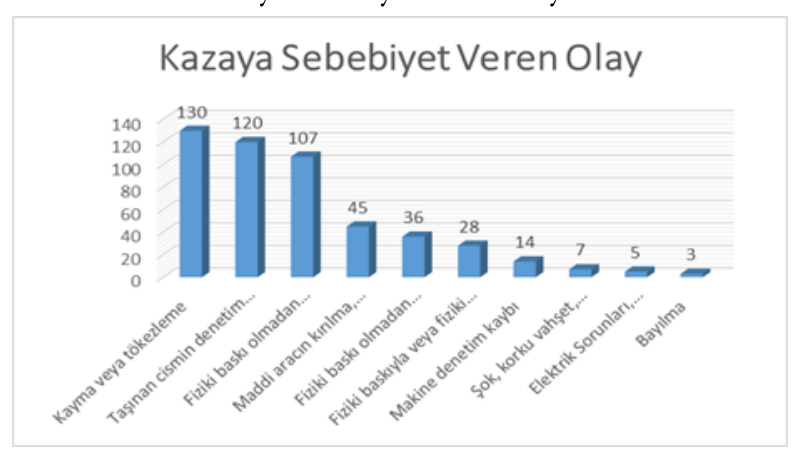

ğında, yani kazanın oluşmasını tetikleyen unsurlar kısmında 10 alt kategoride sonuçlar gruplandırılmıştır. Bu 10 sebep kendi arasında gruplandığında temelde insan faktörü, ekipman faktörü ve sağlık faktörü olarak 3 farklı ana neden elde edilmektedir. Kayma veya tökezleme sebebiyle oluşan kazalar \%26,8 ile en önemli kaza nedeni olarak karşımıza çıkmaktadır. Bu tür kazalar \%36,2 ile en çok 1524 yaş aralığında bulunan genç çalışanlarda yaşanmaktadır. 6 aydan fazla 18 aydan az tecrübesi olan çalşanlar en fazla kayma tökezleme kazası yaşan kişilerdir. Bu kazaların \% 81,5 'i 3 gün ve altında iş günü kaybıyla sonuçlanmıştır. İkinci sırada en çok görülen kazaya sebebiyet veren olay ise taşınan cismin kontrolünün kaybedilmesidir ki tüm kazaların \%22,7’sini oluşturmaktadır. Yürüyen merdivenlerde belirtilen uyarılara rağmen alışveriş arabası gibi uygun olmayan nesnelerin taşınması sonucu oluşan kazalarda hem taşıyan hem de yürüyen merdivende bulunan en az bir kişi daha yaralanmaktadır. Uygunsuz hareket olarak ifade edilen bu kazayı geçirenlerin \%90,1'i temel İSG eğitimi almış kişilerdir. Bu tarz kazaların \%76,4'ünü erkekler yaşamış olup 25-32 yaş aralığı bu kategoride en çok kaza yaşayan aralıktır. 3 ve altında iş günü kaybıyla sonuçlanma oranı ise \%69,1'dir. 107 kaza ise fiziki baskı olmadan beden hareketi kapsamına giren, dikkatsizlik ve dalgınlık gibi nedenlerden kaynaklanmaktadır. Dikkatsizlik, dalgınlık nedeniy-

Şekil 4: Yürüyen merdiven kazalarında yaralanmaya sebebiyet veren hareketler

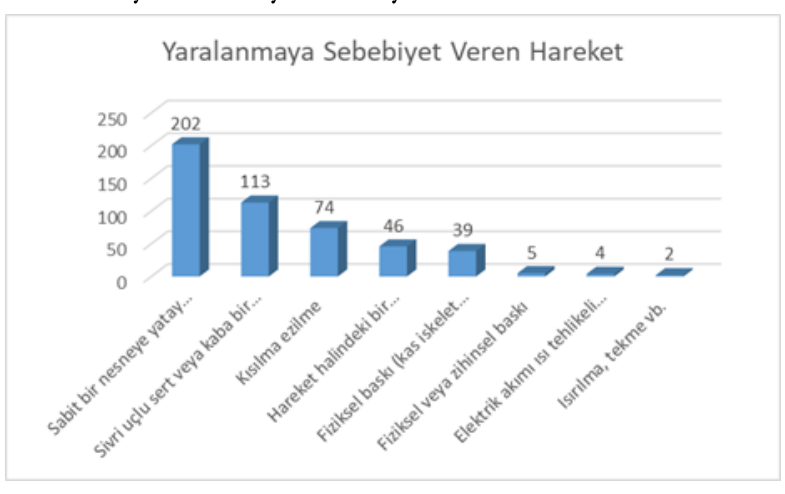


le oluşan kazaların \%70,5'i vücudun bel altı bölgesini etkilemiştir. Bu kategoride yer alan kazaların \%62,6’sını kadınlar yaşamıştır. Gereksiz veya zamansız hareketlerden kaynaklanan kazalar ise tüm kazaların \%7,4’ünü oluştururken bu kazalar sonucu da \%68,8 oranında bel altı bölgesinde yaralanma meydana gelmiştir.

ESAW metodoloji içerisinde "Yaralanmaya Sebep Olan Hareket (Olay)" (bir başka deyişle, yaralanmaya yol açan eylem) sınıflandırması, kazazedenin nasıl yaralandığını ve yaralanmaya neden olan nesne ile nasıl temasa geçtiğini açıklamak üzere tasarlanmıştır. Bu kapsamda yürüyen merdivende yaşanan 485 kaza incelenmiş ve 8 farklı etkileşim türü tanımlanmıştır. Yaşanan kazaların \%41,4’ünün sabit bir nesneye yatay veya düşey darbe(Y1) kategorisinde yer aldığı tespit edilmiştir. \%23,2 ile sivri uçlu sert veya kaba bir materyal ile temas(Y2) en fazla yaralanmaya sebebiyet veren 2. durumu tanımlarken, \%15,2 oranında kaza kısılma, ezilme(Y3) kategorisinde yaşanmıştır. Sabit bir nesneye yatay veya düşey darbe ile oluşan kazaların \%20,8’i burkulma, incinme türü kazalardan oluşurken, sivri uçlu, sert veya kaba bir materyal ile temas sonucu oluşan kazaların \% 38,9'u açık yara şeklinde belirtilen yaralanmalı kazalara sebep olmuştur. Y1 grubu kazaların \%52,5’i alt ekstremite bölgelerini etkilerken, Y2 grubu kazaların \%52,3’ü bel ve üstü vücut bölgelerini etkilemiştir. Hareket halindeki bir nesnenin çarpması ile sonuçlanan kazalarda \%67,6 oranın-

Şekil 5: Yürüyen merdiven kazalarının illere göre dağılımı

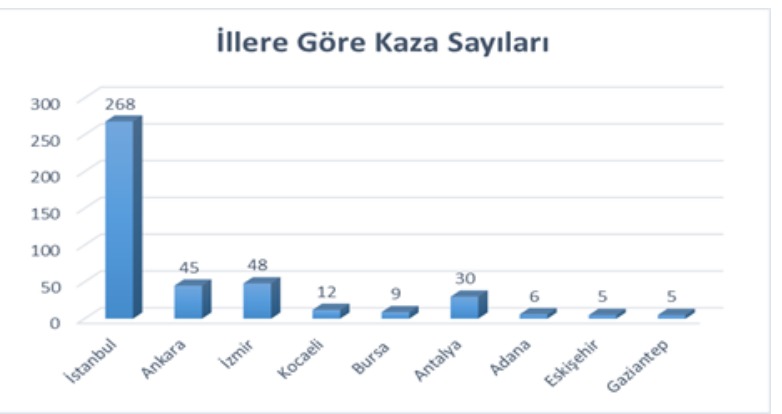

da bel üstü bölgesi etkilenmektedir. Bu tür kazalarda yürüyen merdiven üzerinde seviye olarak aşağıda bulunan kişiye nesne çarpması yaşandığı için bel üstü bölgesini etkileyen kazaların daha sık oluştuğu tespit edilmiştir. Kas iskelet sistemi üzerinde fiziksel baskı nedeniyle oluşan kazalarda ise $\% 78,4$ oranında bel altı bölgesinde yaralanma oluşturan kaza yaşandığı tespit edilmiştir.

2013-2018 yılları arasında yaşanan iş kazası kayıtlarına baktığımızda toplamda 37 farklı ilde yürüyen merdiven kaynaklı iş kazası meydana gelmiştir. Şekil 5'te en çok kaza yaşanan iller verilmiştir. Yaşanan kazaların illere göre dağılımına baktığımızda tüm kazaların \%54’ü İstanbul'da yaşanmıştır. Bu dağılımın oluşmasında yürüyen merdiven sayısının en fazla bulunduğu ilin İstanbul olması doğrudan bir etkendir. İstanbul'da yaşanan kazalar en çok \%16,7 ile 2017 yılında yaşanmış olup, 3 ve altında gün kaybı ile sonuçlanan kaza oranı \%77,2'dir. İstanbul'da yaşanan 268 kazanın \%26,1'inin kayma veya tökezleme sebebiyle oluştuğu tespit edilmiştir. Yaş gruplarına göre bir değerlendirme yapıldığında 32 yaş altı kaza geçiren kişilerin oranı \% $62,5^{\prime}$ tir.

Vücudun etkilenen bölümü kısmı analizlerde değerlendirilirken bel ve üstü vücut bölgeleri, üst ekstremite de dâhil 1 kategori, alt ekstremite bölümleri ise ayrı bir kategori olarak değerlendirilmiştir. Tüm yürüyen merdiven

Şekil 6: Yürüyen merdiven kazalarının vücudun etkilenen kısmına göre dağılımı

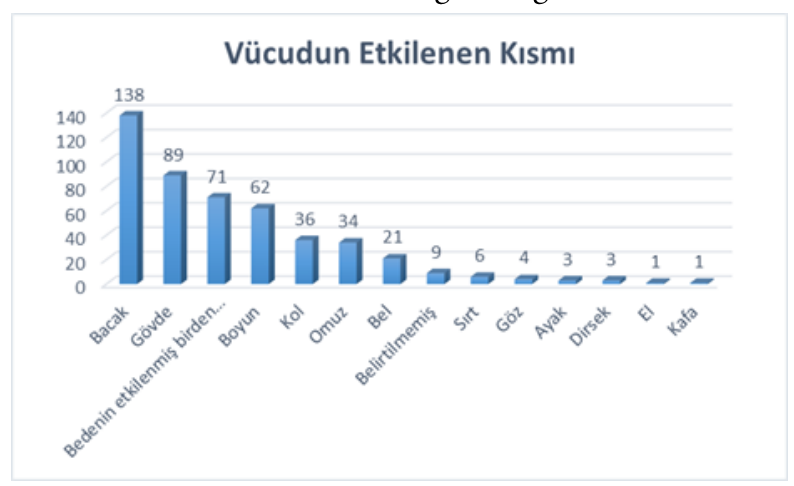


kazaları analiz edildiğinde bacak bölgesinin etkilenmesiyle sonuçlanan kaza oranı $\% 28,3$ ile ilk sırada yer almaktadır. Gövde olarak tariflenen ve vücudun bel ve boyun bölgesi arasında kalan bölgenin etkilenmesiyle sonuçlanan kazalar $\% 18,2$ ile ikinci sırada yer almaktadır. \%14,5 oranında kaza ise vücudun aynı anda birden fazla bölgesini etkilemiştir.

\section{SONUÇ VE TARTIŞMA}

Mevcut çalışma kapsamında 2013-2018 yılları arasında yaşanmış SGK kayıtlarında var olan 485 yürüyen merdiven kazası analiz edilmiştir. Yapılan analiz çalışmaları ESAW metodolojisi kapsamında kategorize edilmiştir. Yapılan analizler sonucu bulgular kısmında belirtilen sonuçlar elde edilmiş olup kaza analizi sonucunda dikkat çeken sonuçlar aşağıda belirtilmiştir.

- İncelemeye alınan dönem içerisinde 2017 yılı \%30,31 kaza oranı ile yürüyen merdiven kazalarının en çok yaşandığı yıl olarak dikkat çekmektedir.

- Xing Y. Ve arkadaşlarının 2020'de yapmış olduğu çalışmada düşme, sıkışma ve düşen nesnelerin çarpması şeklinde 3 farklı durum tanımlanırken, düşme kazalarının oranı \%90 olarak bulunmuştur. Bu çalışmada ise toplamda 8 farklı kategoride yaralanmaya sebebiyet veren hareket(olay) sınıflandırılmıştır. Tüm yürüyen merdiven kazalarının \%41,4'ü sabit bir nesneye yatay veya düşey darbe(Y1) (düşme) kategorisinde yer almaktadır. İki çalışmada da oransal olarak düşme kazaları en yüksek oranda karşılaşılan durum olarak tespit edilmiş$\operatorname{tir}[16]$.

- Yürüyen merdiven kazası geçiren çalışanların $\% 36,1$ 'i 15-24 yaş arasında yer alan çalışanlardır. Yaş ilerledikçe yürüyen merdivende kaza geçirme oranı azalmaktadır. Genç yaş gruplarında, merdiven hareket halindeyken yürünmesi sebebiyle oluşan aceleciliğe bağlı kaza oranının yüksek olduğu düşünülmektedir. Cinsiyete göre değerlendirildiğinde 15-24 yaş aralığındaki kaza geçiren kadınların oranı \%40'dır. Xing Y. ve arkadaşlarının 2019 yilında yapmış olduğu çalışmada 39-65 yaş aralığında yer alan kadınların \%16,92 ile en fazla kazaya yatkın grup olduğu tespit edilmişken, bu çalışma kapsamında 39-65 yaş arasında yer alan kadınların oranı \% 12,7 olarak tespit edilmiştir. Bu oran, yaş aralığına göre kadın çalışanlarda kazaya yatkınlığın en az olduğu yaş aralı̆̆ıdır[6].

- Kayma veya tökezleme nedeniyle oluşan kazalar \%26,8 ile en önemli kaza nedeni olarak karşımıza çıkmaktadır. Yaralanmanın oluşma şekline göre sabit bir nesneye yatay veya düşey darbe(düşme) kazaları ise tüm kazaların \%41,4 üdür. Xing Y. ve arkadaşlarının 2019 yılında yaptıkları araştırma sonucuna göre düşme nedeniyle oluşan kazalar \%91.1 ile en önemli neden olarak bulunmuştur. Aynı zamanda düşme kazalarının \% 31,11'inin ayakta duramama (kayma, takılma vb.) sebebiyle olduğu sonucuna ulaşılmışıı[ 6$]$.

- Cinsiyete göre yürüyen merdiven kazası geçirme oranlarına baktığımızda kazazedelerin \%54,7'si erkek, \% 45,3'ü kadındır. Chi ve arkadaşlarının 2006 yılında yaptıkları çalısmada ise kazazedelerin $\% 67,53$ ü kadındır[9]. O’Neil ve arkadaşlarının 2008 yılında yaptıkları çalışmada ise kadınların yürüyen merdiven kazası geçirme oranı \%72,9 olarak bulunmuştur[2]. Xing Y. ve arkadaşlarının 2019 yılında yürüttükleri çalışmada ise kadınların kaza geçirme oranı \%65,9 olarak bulunmuştur[6]. Howland ve arkadaşlarının 2012 yılında yürüttükleri çalışmada ise kadınların kaza geçirme oranı \%71 olarak belirtilmiştir[13]. Daha önce yapılan çalışmaların aksine bu çalışmada elde edilen veriler ışığında er- 
kekler daha yüksek oranda yürüyen merdiven kazası geçirmektedir. Yürüyen merdivenin kullanımı esnasında meydana gelen kazalarda cinsiyete göre bir farklılık görülmezken yürüyen merdiven tamir, bakım, onarım işlemlerinde kaza geçirenlerin tamamının erkek olması, diğer çalışmalardan farklı olarak bu çalışma kapsamında erkeklerin daha fazla sayıda kaza geçirmesi sonucunu ortaya çıkardığı düşünülmektedir.

- Yürüyen merdiven kazalarının \%40,6'sının yüzeysel yaralanma kategorisinde oluştuğu tespit edilmiştir. 2008 yılında, yaşlıların geçirmiş oldukları yürüyen merdiven kaynaklı kazalar sonucu oluşan yaralanmaların türüne göre yaptıkları incelemede O’Neil ve arkadaşları \%54 oranında kazanın yumuşak doku yaralanmalı kaza olduğu sonucunu bulmuştur. En çok karşılaşılan diğer yaralanma türünün ise \%22 ile kesik, yırtık türü kazalar olduğu belirlenmiştir. En çok görülen 3. durum ise \% 16 ile kırık olarak tespit edilmiştir[2]. Bu çalışma kapsamında açı yara olarak ifade edilen kesik, yırtık türü kazaların oranı \%13 olarak bulunmuşken, kırık vakalarının oranı ise \%7,1 olarak bulunmuştur. Kırık ve açık yara gibi, yüzeysel yaralanmalara göre daha ciddi sonuçları olan kazaların oransal olarak O'Neil ve arkadaşlarının yaptıkları çalışmada yüksek çıkmasının sebebinin inceleme alına alınan grubun yaşıı kişilerden oluşmasından kaynaklandığı düşünülmektedir[2].

- Saatlere göre inceleme yaptğı̆ızda tüm yürüyen merdiven kazalarının \%77,1'i 10:00 ile 18:00 saatleri arasında meydana gelmektedir. Xing Y. ve arkadaşlarının 2020 yılında yaptıkları çalışmada 9:30-17:29 saatleri \% 65 ile en yoğun olarak yürüyen merdiven kazasının yaşandığı saatler olarak tespit edilmiştir[16]. Gündüz kuşağı olarak ifade edilen bu saatler yürüyen merdivenlerin sıklıkla bulunduğu AVM, metro istasyonları gibi insan trafiğinin yoğun olduğu yerlerin doluluk oranlarının yüksek olduğu zamana karşılık gelmektedir.

- 2012 yılında hayatımıza giren İş sağlığı ve güvenliği kanunun bir etkisi olarak tüm çalşanların \%93'ünün İSG eğitimlerini aldığı tespit edilmiştir. İSG eğitimi almış kişilerin geçirdiği 4 ve üstü iş günü kaybıyla sonuçlanan kaza oranı \%22,61 iken, temel İSG eğitimi almayıp 4 ve üstü iş günü kaybıyla sonuçlanan kaza geçirme oranı \%26,47 olarak tespit edilmiştir. Bu sonuç kapsamında kaza şiddetlerine baktığımızda ise eğitim alan kişiler ile almayan kişilerin yaşadıkları iş günü kaybı oransal olarak birbirine yakın bulunmuștur.

- Kazazedelerin \%65,2'si 32 yaş altındadır. Xing Y. ve arkadaşlarının 2020 yılında yaptıkları çalışmada ise kazazedelerin $\% 71$ 'i 40 yaş ve üstünde kişiler olarak tespit edilmiştir[6]. Chi ve arkadaşlarının 2006 yılında yürüyen merdiven kazalarının analizine yönelik yaptıkları çalışmada kazazedelerin \%50,51'inin 65 yaş ve üstü olduğu sonucuna ulaşılmıştır[9].

- Mevsimlere göre bir değerlendirme yapıldığında kış aylarında \%38,4 ile yaz aylarına göre daha fazla sayıda kaza görülmesinin sebebinin özellikle yürüyen merdivenlerin fazla olduğu AVM gibi kapalı alanlara mevsimsel etkilere bağlı olarak kış aylarında daha fazla kişinin gitmesinin sebep olduğu düşünülmektedir.

- 3 ve daha az gün kaybı ile sonuçlanan ve çalışma kapsamında hafif yaralanmalı kaza olarak ifade edilen kazalar tüm yürüyen merdiven kazalarının \%77,1'ini oluşturmaktadır. Xing Y. ve arkadaşlarının 2019 yılında yaptıkları çalışmada kaza sonucu ambulans ihtiyacı olup olmadığına göre kaza ciddiyeti değerlendirilmiştir. Bu çalışmanın sonucunda yürüyen merdiven kazalarının \% 67'sinde ambulans ihtiyacı olmadığı sonucuna ulaşımıştır[6]. Chi ve arkadaşlarının 2006 yılında yaptıkları 
çalışmada ise ambulans ihtiyacı olmayan yürüyen merdiven kazası oranı \%52,8 olarak tespit edilmiştir[9]. Üç çalışmada da elde edilen veriler ş̧ığında yürüyen merdivende yaşanan kaza şiddetinin çoğu kazada düşük olduğu sonucuna ulaşllabilir.

- Yaralanma sonucu vücudun etkilenen kısmıyla ilgili yapılan analizlerde yürüyen merdiven kazaları sonucu en çok \%28,3 ile bacak bölgesi yaralanması yaşanmıştır. Gövde yaralanmaları \%18,2, vücudun birden fazla bölgesini etkileyen kazalar ise \%14,5 ile en çok karşılaşlan 3. durumdur. Xing Y. Ve arkadaşlarının 2020 yılında yaptıkları çalışmada ise vücudun birden fazla bölgesini etkileyen kazaları \%29 ile en çok karşılaşılan durum olurken, \%27 olasılıkla baş ve boyun bölgesi yaralanmalı kazalar bunu takip etmiştir. Gövde yaralanmalı kazalar ise \%10 ile en düşük olasılıkla karşılaşılan kazalar olarak tespit edilmiştir[16]. O’Neil ve arkadaşlarının 2008 yılında yaptıkları çalışmada ise yürüyen merdiven kazalarının \%26'sı alt ekstremite bölgelerinde görülürken, \%25'i baş bölgesi yaralanması olarak tespit edilmiştir[2].

- Yürüyen merdivenlerde belirtilen uyarılara rağmen, alşsveriş arabası, bebek arabası, valiz, çanta gibi uygun olmayan nesnelerin taşınması sırasında yaşanan kazalar sonucu hem taşıyan hem de yürüyen merdivende bulunan en az bir kişi daha yaralanmalı kaza geçirmektedir. Uygunsuz hareket olarak ifade edilen bu tür kazayı yaşayanların \%90,1'i İSG eğitimi almış çalışanlardır. Taşınan cismin kontrolünün kaybedilmesi sonucu oluşan kazalar İSG eğitimi almış çalışanlar için \%22,17 oranında meydana gelirken İSG eğitimi almamış çalışanlarda bu kaza sebebi \%29,41 olarak tespit edilmiştir. Xing Y. ve arkadaşlarının 2019 yılında yürüttükleri çalışmada 950 kazanın 148 'inde kişinin yürüyen mer- divende valiz taşıdı̆̆ı, 12 kişinin ise bebek arabası veya alışveriş arabası taşıması sebebiyle kaza yaptığı tespit edilmiştir. Cohen ve Compton'ın 1980 yılında yürüttükleri çalışmada da tüm kazaların \%13’ünün valiz vb. eşya taşınmasından kaynaklı olduğuna vurgu yapılmış$\operatorname{tır}[21] . B u$ çalışmada ise hareket halindeki bir nesnenin çarpması (alışveriş arabası, bebek arabası vb.) sebebiyle yaşanan kazaların oranı \%9,4 olarak tespit edilmiştir.

- Özellikle bakım, onarım ve kurulum aşamalarında karşılaşılan açı yara ile sonuçlanan kazalara odaklanarak ve bu noktada iyileşme sağlanarak yürüyen merdivende yaşanan işgünü kayıplı kaza sayısında bir iyileştirme yaşanması mümkün gözükmektedir.

Çalışma kapsamında özellikle 6331 sayılı İşs sağlığı ve güvenliği kanunu hayata girdikten sonra daha sistemli kaza kayıtlarının tutulmaya başlandığı dönem olan 2013 yılı başlangıç olarak alınmıştır. Mevzuat düzenlemesine rağmen kayıt tutma noktasındaki yetersizliklerin sürdüğü düşünülmektedir. Türkiye'de İSG alanında yapılmış olan bilimsel çalışmaların çoğu, ülkemizin iş kazası veri toplama sistemindeki yetersizliklerden dolayı anket sonuçları dayanak alınarak gerçekleştirilmektedir[22]. Bu makale kapsamında, anket sonuçları yerine SGK kayıtlarına girmiş kaza bilgilerini içeren bir veri seti kullanılmıştır. Çalışma kapsamında elde edilen veriler İSBY üzerinden alınan yaşanmış kaza verileri olup çok sayıda bilgi içermesine rağmen ayrıntılı çalışmaların yapılabilmesi adına kullanışlı veri eksikliği bulunmaktadır. Yürüyen merdivenlerin kapasite, hız, fiziksel ölçüleri, yürüyen merdivendeki kaza lokasyonu, kazaya karışan nesne (valiz, alışveriş arabası vb.), gibi bilgilerin elde edilebilir olması daha ayrıntılı analizlerin yapılabilmesine imkân sağlayacaktır. Yürüyen merdivenler ile ilgili istatistikler üzerinden gerçekleştirilen çalışma farkındalık ve bilinç noktasında sahaya katkı sağlayacak ve yapılacak yeni çalışmalar için bir temel oluşturacaktır. 
YAZAR KATKILARI: Araştırma fikrinin oluşturulması, tasarımı AKÇ-HBU, veri toplanması AKÇ, analiz, yorum ve makalenin yazılması AKÇ-HBU tarafından yapılmıştır.

ÇıKAR ÇATışMASı: Yazarlar herhangi bir çıkar çatışması olmadığını, makalede araştırma ve yayın etiğine uyulduğunu beyan ederler.

Finansal Destek: Bu çalışmada herhangi bir kişi, kurum veya kuruluştan finansal destek alınmamıştır.

Етік Коміте ONAYı: Yazarlar çalışmada insandan anket, mülakat, odak grup çalışması, deney vb. yollarla veri toplanması ve/veya insan ve hayvanların deneysel ya da diğer bilimsel amaçlarla kullanılması faaliyetlerini içermediği için etik kurul onay belgesi gerektirmediğini, ayrıca makalede araştırma ve yayın etiğine uyulduğunu beyan ederler.

\section{KAYNAKÇA}

[1] Staal J and John Quackenbush. 1998. Elevators, Escalators and Hoists. In: Stellman, Jeanne Mager, ed. Encyclopaedia of Occupational Health and Safety, Fourth Edition. Geneva: International Labour Office., Volume III, chapter 93, pp. 40-44.

[2] O’Neil J, Steele GK, Huisingh C, Smith GA. Escalator-related injuries among older adults in the United States, 1991-2005.Accid Anal Prev. 2008;40(2):52733. doi: 10.1016/j. aap.2007.08.008. Epub 2007 Sep 10.

[3] Karatekin E. (2014). Mevcut Yürüyen Merdivenler Ve Bantların Güvenlik İyileştirmesi. Asansör Sempozyumu / İzmir

[4] Dhanasekaran R., Vinothkanna R., Sreenatha Reddy S. Narendra Kumar M. \& Bala Arogya Kaiyan P. (2016). A Review of Escalator Accidents and Preclusion. GRD Journals- Global Research and Development Journal for Engineering, 1(12), 132-136.

[5] Schminke H., Jeger V., Evangelopoulos S., Zimmerman H. \& Exadaktylos K. (2012) Riding the Escalator: How Dangerous is it Really? Western Journal of Emergency Medicine: Integrating Emergency Care with Population Health, 14(2), 141-145.

[6] Xing Y., Dissanayake S., Lu J., Long S. \& Lou Y. (2019) An analysis of escalator-related injuries in metro stations in China, 2013-2015. Accident Analysis and Prevention 122, 332-341.

[7] Platt L., Fine S. \& Foltin L. (1997) Escalator-related Injuries in Children. Pediatrics, 100;e2. DOI: 10.1542/peds.100.2.e2

[8] Mcgeehan J., Shields J., Wilkins R, Ferketich K., \& Smith A. (2006) Escalator-Related Injuries Among Children in the United States, 1990-2002. Pediatrics 118. e279-e285.

[9] Chi F., Chnag C. \& Tsou C. (2006). In-depth investigation of escalator riding accidents in heavy capacity MRT stations. Accident Analysis and Prevention 38. 662-670.

[10] Nicolson, C. Risk Mitigation Associated with Airport Escalator and Moving Sidewalk Operations; International Association of Airport Executives Canada: Calgary, AB, Canada, 2008.

[11] Mccann, M.; Zaleski, N. Deaths and injuries involving elevators and escalators. Cent. Constr. Res. Train. 2006, 7, 1-21.

[12] Lee D., Kim C., Kim S. \& Lee S. (2010) An analysis of escalator-related injuries in an emergency department. Hong Kong Jounal of emergenct Medicine. 2010-17. 212-217.

[13] Howland, J., Bibi, S., English, J., Dyer, S., Peterson, E.W., (2012). Older adult falls at a metropolitan airport: 2009-2010. J. Safety Res. 43 (2), 133-136.

[14] Chen, Z.; Xian, J. (2016) 609 escalator-related injuries against preschoolers: An in-depth investigation in Guangdong Injury Prevention 22(Suppl 2):A218.2 $-\mathrm{A} 219$

[15] Basir, F.A.M.; Yaziz, A.H.; Zamri, M.H.; Halim, A.H.A. Escalator accidents: Causes and users' behavior Empirical Study of Kuala Lumpur Users In Proceedings of the 2nd Advances in Business Research International Conference, Singapore, 18 October 2017

[16] Xing Y., Chen S., Zhu S. and Lu J. (2020), Analysis Factors That Influence Escalator-Related Injuries in Metro Stations Based on Bayesian Networks: A Case Study in China. International Journal of Enviromental Research and Public Health. 17(2), 481; https:// doi.org/10.3390/ijerph17020481

[17] https://ibys.csgb.gov.tr/ Erişim Tarihi:12.01.2020

[18] https://ec.europa.eu/eurostat/ documents/3859598/5926181/KS-RA-12-102EN.PDF/56cd35ba-1e8a-4af3-9f9a-b3c47611ff1c Erişim Tarihi: 12.01 .2020 
[19] Kazan, E., E., (2013). Analysis of Fatal and Nonfatal Accidents Involving Earthmoving Equipment Operators and On-Foot Workers, Doktora Tezi, Wayne State Uni., Amerika Birleşik Devletleri

[20] Yılmaz F. \& Tan O. (2015). Bir İnşaat Şantiyesinde İş Kazalarının Neden Olduğu İşgünü Kayıplarının İşverene Maliyetinin Belirlenmesi. International Journal of Economic and Administrative Studies. 14. 144-155.

[21] Cohen, H.H., Compton, D.M., 1982. Fall accident patterns: characterization of most frequent work surface-related injuries Prof. Saf. 27 (6), 16-22.

[22] Baradan S., Akboğa Ö., Çetinkaya U. \& Usmen M. (2016) Ege Bölgesindeki İnşaat İş Kazalarının Sıklık ve Çapraz Tablolama Analizleri. İMO Teknik Dergi 7345-7370 